\title{
Cenderitide (CD-NP), a novel peptide designed to activate both guanylyl cyclase $B$ and $A$, activates the second messenger cGMP, suppresses aldosterone, and preserves GFR without reducing blood pressure in a proof-of-concept study in patients with chronic heart failure
}

\author{
Lisa C Costello-Boerrigter ${ }^{*}$, John A Schirger, Wayne L Miller, Guido Boerrigter, Horng H Chen, Ruth Kempf, \\ Candace Y Lee, John C Burnett Jr
}

From 5th International Conference on cGMP: Generators, Effectors and Therapeutic Implications Halle, Germany. 24-26 June 2011

\section{Background}

The development of new therapies for heart failure (HF) is a high priority. The endogenous natriuretic peptides (NPs) ANP, BNP, and CNP mediate cardiac unloading, renal enhancing, vasoprotective and RAAS suppressing actions via activation of the receptors guanylyl cyclase (GC)-A and GC-B, respectively. We engineered cenderitide (also known as $\mathrm{CD}-\mathrm{NP}$ ) as a novel $\mathrm{NP}$ that activates both GC-A and GC-B, with higher activity at GC-B so as to be less hypotensive than the GC-A agonists ANP and BNP. The cardiorenal and neurohumoral actions of cenderitide in HF patients are undefined. We hypothesized that cenderitide would suppress RAAS via GC-A activation, would unload the heart while maintaining blood pressure (BP) taking advantage of GC-B activation, and would preserve glomerular filtration rate (GFR) secondary to both GC-A and GC-B.

\section{Methods}

Subjects with stable, chronic HF (ejection fraction $\leq 40 \%$ ) were enrolled in a randomized, double-blind, placebo-controlled, proof-of-concept study. Randomization was to either placebo $(n=5)$ or cenderitide $(20$

\footnotetext{
* Correspondence: costello.lisa@mayo.edu

Cardiorenal Research Laboratory, Mayo Clinic, Rochester, MN, USA
}

ng/kg/min; $\mathrm{n}=9$; Nile Therapeutics) for 4 hours. On the study day, patients received their usual cardiac medications except diuretics. GFR was measured by iothalamate. BP, aldosterone and ANP were also assessed, the latter to assess cardiac unloading. After equilibration, a $60^{\prime}$ baseline clearance $(\mathrm{C} 1)$ was done, followed by two $120^{\prime}$ clearances ( $\mathrm{C} 2$ and $\mathrm{C} 3$, respectively) with cenderitide or placebo, and finally a 120' post-infusion clearance (C4). Changes from baseline were compared between groups. p-values are cenderitide vs. placebo.

\section{Results}

Cenderitide increased cGMP, the second messenger of the NPs, in C2 and C3 ( $\mathrm{p}<0.05)$. Cenderitide as compared to placebo did not change BP or heart rate. GFR $(p=0.04)$ increased with cenderitide in $\mathrm{C} 2$. Cenderitide decreased aldosterone in $\mathrm{C} 3(\mathrm{p}=0.01)$ and tended to do so in $\mathrm{C} 2(\mathrm{p}=0.054)$. Cenderitide decreased ANP in C4, consistent with greater cardiac unloading.

\section{Conclusion}

Cenderitide represents a novel dual activator of GC-A and GC-B which in human HF is safe, activates cGMP, suppresses aldosterone, unloads the heart and preserves renal function at a non-hypotensive dose. Further 
investigations of this promising new therapeutic strategy for HF are warranted.

Published: 1 August 2011

doi:10.1186/1471-2210-11-S1-P18

Cite this article as: Costello-Boerrigter et al:: Cenderitide (CD-NP), a novel peptide designed to activate both guanylyl cyclase $B$ and $A$, activates

the second messenger cGMP, suppresses aldosterone, and preserves GFR without reducing blood pressure in a proof-of-concept study in patients with chronic heart failure. BMC Pharmacology 2011 11(Suppl 1): P18.

Submit your next manuscript to BioMed Central and take full advantage of:

- Convenient online submission

- Thorough peer review

- No space constraints or color figure charges

- Immediate publication on acceptance

- Inclusion in PubMed, CAS, Scopus and Google Scholar

- Research which is freely available for redistribution

Submit your manuscript at www.biomedcentral.com/submit 